\title{
Sediment Accumulation in Prairie Wetlands under a Changing Climate: the Relative Roles of Landscape and Precipitation
}

\author{
Susan K. Skagen $^{1}$ • Lucy E. Burris ${ }^{2,1}$ • Diane A. Granfors ${ }^{3}$
}

Received: 24 August 2015 / Accepted: 2 February 2016/Published online: 22 February 2016

(C) The Author(s) 2016. This article is published with open access at Springerlink.com

\begin{abstract}
Sediment accumulation threatens the viability and hydrologic functioning of many naturally formed depressional wetlands across the interior regions of North America. These wetlands provide many ecosystem services and vital habitats for diverse plant and animal communities. Climate change may further impact sediment accumulation rates in the context of current land use patterns. We estimated sediment accretion in wetlands within a region renowned for its large populations of breeding waterfowl and migrant shorebirds and examined the relative roles of precipitation and land use context in the sedimentation process. We modeled rates of sediment accumulation from 1971 through 2100 using the Revised Universal Soil Loss Equation (RUSLE) with a sediment delivery ratio and the Unit Stream Power Erosion Deposition model (USPED). These models predicted that by 2100, 21$33 \%$ of wetlands filled completely with sediment and $27-$ $46 \%$ filled by half with sediments; estimates are consistent with measured sediment accumulation rates in the region reported by empirical studies. Sediment accumulation rates were strongly influenced by size of the catchment, greater coverage of tilled landscape within the catchment, and steeper
\end{abstract}

Electronic supplementary material The online version of this article (doi:10.1007/s13157-016-0748-5) contains supplementary material, which is available to authorized users.

Susan K. Skagen

skagens@usgs.gov

1 U.S. Geological Survey, Fort Collins Science Center, 2150 Centre Avenue, Bldg. C, Fort Collins, CO 80526, USA

2 Colorado State University, Fort Collins, CO 80523, USA

3 U.S. Fish and Wildlife Service, 1011 East Tudor Rd, Anchorage, AK 99503, USA slopes. Conservation efforts that incorporate the relative risk of infilling of wetlands with sediments, thus emphasizing areas of high topographic relief and large watersheds, may benefit wetland-dependent biota.

Keywords Climate change $\cdot$ Northern Great Plains $\cdot$ Revised Universal Soil Loss Equation · Sedimentation · Stream Power Erosion Deposition Model $\cdot$ Wetland

\section{Introduction}

Naturally formed depressional wetlands of midcontinental North America provide vital habitats that support biodiversity at many trophic levels, including terrestrial wildlife species (Tiner 2003). These wetlands also deliver numerous ecosystem services, including surface-water storage and flooddamage protection, ground-water recharge, and global cycling of nutrients (van der Kamp and Hayashi 1998; Tiner 2003; Smith et al. 2011). Many of these wetlands are completely surrounded by upland and are highly vulnerable to land conversion, habitat fragmentation, water pollution, ground-water withdrawal, and drought (Donald et al. 1999; Gleason et al. 2003; Tiner 2003). Sediment accumulation can also threaten the viability and hydrologic functioning of many wetlands embedded within the agricultural landscapes of the Great Plains (Smith et al. 2011; Burris and Skagen 2012; Daniel et al. 2014). For example, nearly $90 \%$ of the shallow depressional wetlands, or playas, in the west-central Great Plains are predicted to completely fill with sediments by 2100 (Burris and Skagen 2012).

The Prairie Pothole Region (PPR) within the north-central United States (U.S., U.S. PPR) is renowned for its ecological value and has the greatest density of naturally formed wetlands in the continental U.S., with $>2.6$ million wetlands in 
North Dakota and South Dakota (Reynolds et al. 2006). These prairie wetlands provide breeding habitat for $50-80 \%$ of the continent's waterfowl (Batt et al. 1989), including ca 4 million breeding pairs of dabbling ducks (Reynolds et al. 2006), and support $>7$ million en route migrant shorebirds during spring migration (Niemuth et al. 2006; Skagen et al. 2008). Many wetlands of the U.S. PPR have been modified or eliminated though agricultural intensification over the past 200 years (Tiner 1984; Dahl 2011), and conversion of native landscapes to cropland continues today (Sylvester et al. 2013). In response to a recent rise in commodity prices and demand for biofuels, a pulse of grassland conversion to corn and soybean cropping has occurred in the last decade on lands with high erosion risk and in close proximity to wetlands (Johnston 2013; Wright and Wimberly 2013).

Sediment accumulation in wetlands is a natural process that is greatly accelerated by cultivation practices (Gleason and Euliss 1998; Smith et al. 2011; Burris and Skagen 2012). Sediments eroded from surrounding upland soils accumulate in wetland basins and decrease basin volume, leading to altered hydrologic function, shortened effective life-span, and diminished ecological utility of wetlands (Gleason and Euliss 1998; Tangen and Gleason 2008). As little as $0.5 \mathrm{~cm}$ of sediment is sufficient to significantly reduce emergence of both wetland seedlings and invertebrates, the primary food base of wetland-dependent vertebrates (Jurik et al. 1994; Gleason et al. 2003). Furthermore, when sediments diminish basin depth to $<1 \mathrm{~m}$, tall robust emergent perennials such as cattails (Typha spp.) easily outcompete annual species to eliminate open shoreline and open water habitats important to waterfowl and shorebirds (Gleason 2001:11).

Impending climate change may significantly impact rainfall runoff-driven sediment accumulation rates in the context of current land use patterns if precipitation patterns and amount differ substantially from contemporary climates. Increases in annual precipitation, changing seasonal precipitation patterns, and higher summer temperatures are predicted across the northern Great Plains by atmospheric-oceanic general circulation models (AOGCMs; Christensen et al. 2007; Ballard et al. 2014). Here we examine the relative roles of increasing precipitation and land use context in the sedimentation process across the U.S. portion of the Prairie Pothole Region.

We modeled rates of sedimentation, sediment depths, and resultant depths of palustrine wetlands across the U.S. PPR from 1971 through 2100 . We estimated erosion using two methods, (1) the Revised Universal Soil Loss Equation (RUSLE; Renard et al. 1997), a field-scale analysis approach applied at the regional scale, which included upland land use, general topography, erosivity (estimated from precipitation), soil texture, and conservation practice inputs; and (2) the Unit Stream Power Erosion Deposition model (USPED; Mitasova et al. 1996), an improved method that also accounted for topographic complexity of the landscape. Both methods assume overland flow of runoff water from rainfall as the sole mechanism for sediment transport. Conservation planning for these critical wetlands and their associated biota will be informed by the spatially explicit predictions of wetland sediment accumulation patterns.

\section{Methods}

\section{Study Area}

Modern day pothole wetlands within the Prairie Pothole Region were formed as the ice sheet of the Wisconsin glaciations retreated 12,000 to 10,000 years ago (Kehew and Teller 1994), leaving depressions that filled with water to form wetlands of varying types: lakes and semipermanent wetlands that are hydrologically connected to groundwater, and shallower temporary and seasonal wetlands that fill with precipitation and runoff (Winter and Rosenberry 1995). Our 350,000 km study area in the U.S. PPR extended across parts of North Dakota, South Dakota, Minnesota, and Iowa, USA, and spanned several major physiographic regions (Fig. 1). Elevation ranges from 200 to 750 masl (Gesch et al. 2002; Gesch 2007). The eastern lower elevation and relatively flat areas are known primarily as the drift prairies, although for simplicity, we have grouped this physiographic region with Glacial Lake Agassiz, which extends along the eastern border of North Dakota. Along the south-central and western sides of the study area rise the Prairie and Missouri coteaus, hilly moraines of glacial debris now covered with grassland and wetlands.

The rich prairie soils of the drift prairies have been extensively converted to agriculture, with $<1 \%$ remaining in native prairie in Minnesota and Iowa. Drainage of $50 \%$ of wetland basins in Minnesota and $97 \%$ in Iowa have accompanied this conversion (Dahl 1990; Dahl 2011). The landscape has been less altered in the Dakotas, with about $40 \%$ of wetlands drained and $27 \%$ remaining in native cover; the thinner, rockier soils of the coteaus are better suited to grass-based agriculture (i.e., grazing and haying) than production of crops through tillage. The climate is spatially variable and highly dynamic between years in temperature (ranging from $-40{ }^{\circ} \mathrm{C}$ in winter to $40{ }^{\circ} \mathrm{C}$ in summer) and in annual precipitation (ranging from $300 \mathrm{~mm} \mathrm{yr}^{-1}$ in the northwestern region to $900 \mathrm{~mm} \mathrm{yr}^{-1}$ in the southeast; Millett et al. 2009).

\section{Spatial Data}

Wetland basin perimeters were developed by the U.S. Fish and Wildlife Service Habitat and Population Evaluation Team as defined in Cowardin (1982); Cowardin et al. (1995) and Johnson and Higgins (1997), where each basin is defined 
Fig. 1 Subecoregions and elevation profile within the study region portion of the U.S. Prairie Pothole Region (U.S. PPR). Inset map shows the full extent of U.S. PPR

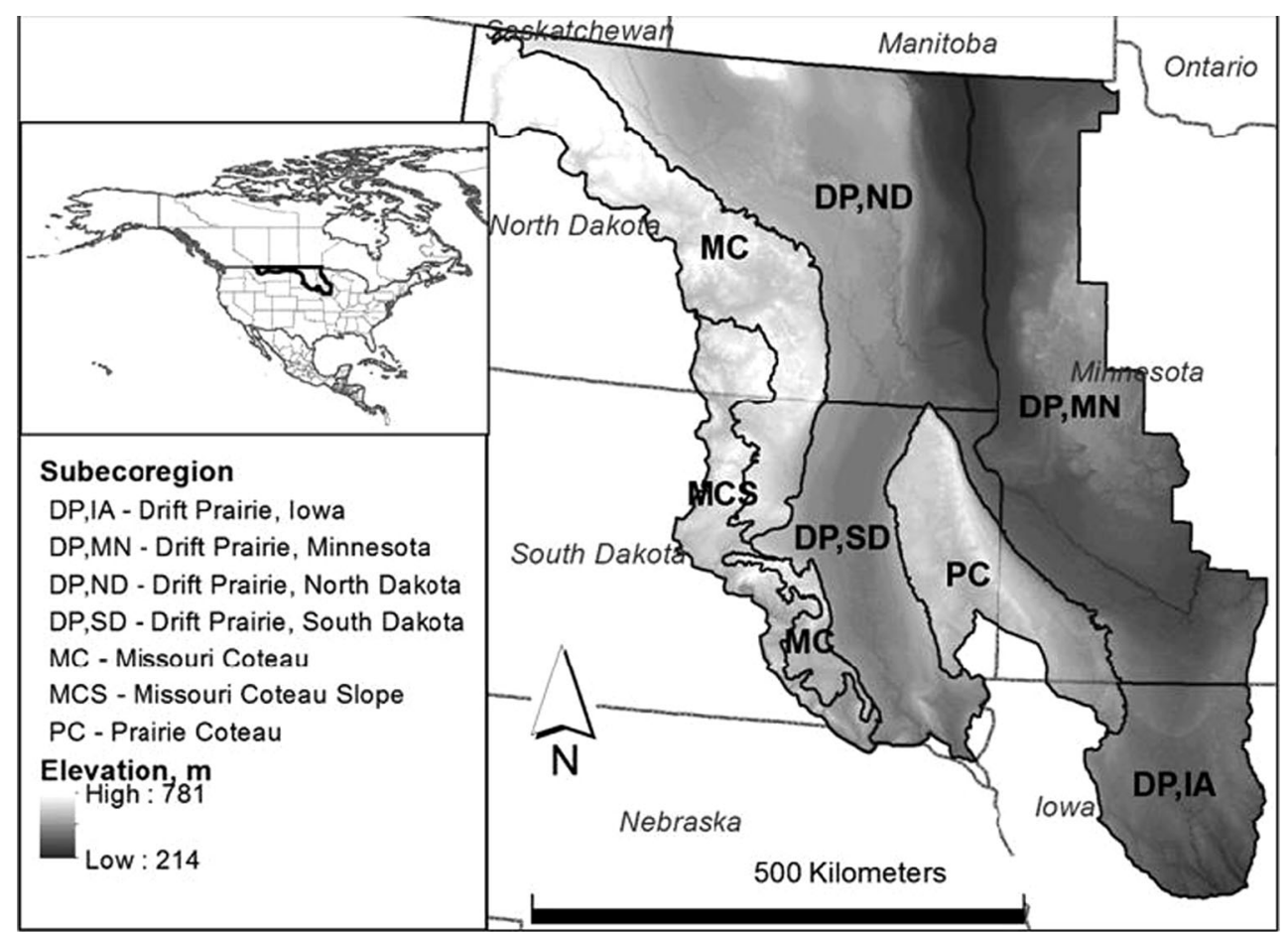

by the deepest water regime within contiguous wetlands delineated by the National Wetlands Inventory (NWI; U.S. Department of the Interior 2009. We included wetlands ranging from temporary (holding water for a few weeks at the start of the growing season), seasonal (holding water approximately one month into the growing season), semipermanent (holding water throughout the growing season) to permanent (or lakes, holding water throughout the year) (Cowardin et al. 1995). We excluded riverine wetlands and the "saturated" wetland category that was delineated only in Minnesota.

We used the ESRI ArcGIS WATERSHED command (ESRI 1999-2008) with 1 arc-second elevation data (Gesch et al. 2002; Gesch 2007) to establish flow direction with wetland basins as pourpoints and to determine the surrounding catchment area that could contribute sediment into each wetland basin (Online Resource 1, Fig. S2). We estimated basin volume by assigning basins to subecoregions of the PPR and using equations developed by Gleason et al. (2007: Table 1) based on survey-based morphometry data. All calculations were conducted on 30-m $\times 30-\mathrm{m}$ grid cells. We estimated sediment accumulation rates for catchments larger than our minimum mapping unit $\left(900 \mathrm{~m}^{2}\right)$ and for which all input values (slope, land use, soil erodibility, and rainfall erosivity) were available.

For computations of erosivity (R), we used historical precipitation data (1981-2010) for reference conditions and downscaled $8-\mathrm{km}$ resolution precipitation data from three AOGCMs (the Australian Commonwealth Scientific and Industrial Research Organization model CSIRO-MK3.5, the Canadian Centre for Climate Modeling and Analysis model
CGCM2.1MR, and the Japanese Centre for Climate System Research Model for Interdisciplinary Research on Climate model MIROC Version 3.2) and three IPCC 4 (United Nations Intergovernmental Panel on Climate Change Fourth Assessment) emissions scenarios: A1B, A2, and B1 (in broad terms, representing continuing current greenhouse gas emission rates, significant emissions increases, and emissions reduction, respectively) (Coulson et al. 2010; Pachauri and Reisinger 2007).

Erosivity (R) was computed based solely on total annual precipitation after Renard and Freimund (1994: Eqns. 11, 12):

$$
\begin{aligned}
R & =0.04830 P^{1.610}, \text { when } P<850 \mathrm{~mm} \mathrm{yr}^{-1} \text { or } \\
R & =587.8-1.219 P+0.004105 P^{2}, \text { when } P \\
& >850 \mathrm{~mm} \mathrm{yr}^{-1}
\end{aligned}
$$

At $850 \mathrm{~mm} \mathrm{yr}^{-1}$, values from the two equations were essentially the same. $R$ was in units of MJ $\cdot \mathrm{mm} \cdot \mathrm{ha}^{-1} \cdot \mathrm{hr}^{-1} \cdot \mathrm{yr}^{-1} \cdot R$ was calculated for each $8-\mathrm{km}$ grid cell for each year and summed for the 30-yr periods 1980-2010, 2011-2040, 2041-2070, and 2071-2100. Separate $R$ grids were created for each climate model, emission scenario, and 30-yr period.

Soil erodibility $(\mathrm{K})$ and oven dry weight (bulk density, $\rho$ ) were extracted from the Soil Survey Geographic (SSURGO) database from the National Resource Conservation Service (NRCS; Soil Survey Staff 2009). The cover factor (C) was determined from landcover data. We used state-level landcover data based on 2000-2001 Landsat Thematic 
Table 1 Predicted loss of palustrine wetland basins by regime by 2100 due to sediment accumulation. Revised Universal Soil Loss Equation $\left(\right.$ RUSLE $\left._{s d r}\right)$ model with a sediment delivery ratio and the Unit Stream
Power Erosion Deposition (USPED) model were applied to subecoregions of the U.S. Prairie Pothole Region using nine averaged scenario-model combinations of projected climate change models

\begin{tabular}{|c|c|c|c|c|c|c|c|c|c|}
\hline \multirow[t]{2}{*}{ Subecoregion } & \multirow[t]{2}{*}{ Method } & \multicolumn{2}{|l|}{ Temporary } & \multicolumn{2}{|l|}{ Seasonal } & \multicolumn{2}{|c|}{ Semipermanent } & \multicolumn{2}{|c|}{ All Palustrine Wetlands } \\
\hline & & $\begin{array}{l}\text { Total } \\
\text { Wetlands }\end{array}$ & $\begin{array}{l}\text { Wetlands } \\
\text { Filled (\%) }\end{array}$ & $\begin{array}{l}\text { Total } \\
\text { Wetlands }\end{array}$ & $\begin{array}{l}\text { Wetlands } \\
\text { Filled (\%) }\end{array}$ & $\begin{array}{l}\text { Total } \\
\text { Wetlands }\end{array}$ & $\begin{array}{l}\text { Wetlands } \\
\text { Filled (\%) }\end{array}$ & $\begin{array}{l}\text { Total } \\
\text { Wetlands }\end{array}$ & $\begin{array}{l}\text { Wetlands } \\
\text { Filled }(\%)\end{array}$ \\
\hline Drift Prairie, ND & $\begin{array}{l}\text { RUSLE }_{s d r} \\
\text { USPED }\end{array}$ & 166,302 & $\begin{array}{l}51,286(31) \\
40,439(24)\end{array}$ & 250,962 & $\begin{array}{l}80,200(32) \\
45,880(18)\end{array}$ & 42,581 & $\begin{array}{l}11,218(26) \\
4904(12)\end{array}$ & 459,845 & $\begin{array}{l}142,704(31) \\
91,223(20)\end{array}$ \\
\hline Drift Prairie, MN & $\begin{array}{l}\text { RUSLE }_{s d r} \\
\text { USPED }\end{array}$ & 44,934 & $\begin{array}{l}18,747(42) \\
12,201(27)\end{array}$ & 104,209 & $\begin{array}{l}53,555(51) \\
25,182(24)\end{array}$ & 38,357 & $\begin{array}{l}16,652(43) \\
6546(17)\end{array}$ & 187,500 & $\begin{array}{l}88,955(47) \\
43,929(24)\end{array}$ \\
\hline Drift Prairie, IA & $\begin{array}{l}\text { RUSLE }_{s d r} \\
\text { USPED }\end{array}$ & 8656 & $\begin{array}{l}4836(56) \\
3009(35)\end{array}$ & 10,191 & $\begin{array}{l}7179(70) \\
4223(41)\end{array}$ & 2991 & $\begin{array}{l}1665(56) \\
1076(36)\end{array}$ & 21,838 & $\begin{array}{l}13,681(63) \\
8308(38)\end{array}$ \\
\hline Drift Prairie, SD & $\begin{array}{l}\text { RUSLE }_{s d r} \\
\text { USPED }\end{array}$ & 145,660 & $\begin{array}{l}41,478(29) \\
36,083(25)\end{array}$ & 94,286 & $\begin{array}{l}23,869(25) \\
16,810(18)\end{array}$ & 23,688 & $\begin{array}{l}5762(24) \\
3782(16)\end{array}$ & 263,634 & $\begin{array}{l}71,110(27) \\
56,676(22)\end{array}$ \\
\hline Prairie Coteau & $\begin{array}{l}\text { RUSLE }_{s d r} \\
\text { USPED }\end{array}$ & 42,589 & $\begin{array}{l}17,683(42) \\
12,912(30)\end{array}$ & 57,900 & $\begin{array}{l}20,764(36) \\
12,666(22)\end{array}$ & 30,720 & $\begin{array}{l}8400(27) \\
4358(14)\end{array}$ & 131,209 & $\begin{array}{l}46,847(36) \\
29,936(23)\end{array}$ \\
\hline $\begin{array}{l}\text { Missouri Coteau } \\
\text { Slope }\end{array}$ & $\begin{array}{l}\text { RUSLE }_{s d r} \\
\text { USPED }\end{array}$ & 6013 & $\begin{array}{l}2112(35) \\
1871(31)\end{array}$ & 5910 & $\begin{array}{l}2057(35) \\
1424(24)\end{array}$ & 2054 & $\begin{array}{l}836(41) \\
620(30)\end{array}$ & 13,977 & $\begin{array}{l}5004(36) \\
3915(29)\end{array}$ \\
\hline Missouri Coteau & $\begin{array}{l}\operatorname{RUSLE}_{s d r} \\
\text { USPED }\end{array}$ & 138,743 & $\begin{array}{l}43,746(32) \\
36,996(27)\end{array}$ & 285,325 & $\begin{array}{l}83,155(29) \\
44,928(16)\end{array}$ & 66,146 & $\begin{array}{l}16,082(24) \\
8220(12)\end{array}$ & 490,214 & $\begin{array}{l}142,982(29) \\
90,144(18)\end{array}$ \\
\hline $\begin{array}{l}\text { All } \\
\text { subecoregions }\end{array}$ & $\begin{array}{l}\text { RUSLE }_{s d r} \\
\text { USPED }\end{array}$ & 552,897 & $\begin{array}{l}179,889(33) \\
143,510(26)\end{array}$ & 808,783 & $\begin{array}{l}270,779(34) \\
151,115(19)\end{array}$ & 206,537 & $\begin{array}{l}60,615(30) \\
29,506(15)\end{array}$ & $1,568,217$ & $\begin{array}{l}511,282(33) \\
324,131(21)\end{array}$ \\
\hline
\end{tabular}

Mapper satellite imagery that differentiated grass, hay, and cropland, the primary land uses in the U.S. PPR (Thogmartin et al. 2004). We compared land use and 1997 National Resources Inventory sub-county $\mathrm{C}$-factor values (Natural Resources Conservation Service 2000) to assign values of $0.19,0.02$, and 0.01 to cropland, hayland, and grassland, respectively (Online Resource 1, Table S1). Here grasslands are considered native, and haylands are modified by grazing, mowing, irrigation, or seeding.

\section{Model Application}

We used RUSLE and USPED to estimate sediment loss from each catchment (drainage area surrounding each wetland basin) into its associated wetland basin. RUSLE was originally designed for use on short slopes without redeposition of sediments along the slope (hereafter, intermediate redeposition). RUSLE can be used with a sediment delivery ratio ( $s d r$; USDA Soil Conservation Service 1983) to account for the unmodeled processes of intermediate redeposition on long and/or complex slopes (RUSLE Rdr $_{s}$ ). USPED was based upon RUSLE but uses a stream power model in a geographical information systems (GIS) framework to account for intermediate redeposition and differing rates of erosion on slopes (Mitasova et al. 2003). Because USPED accounts for intermediate redeposition of sediments, it provides a more conservative estimate of sediment accumulation in wetlands than does RUSLE without a sediment delivery ratio. Due to its use of local topographic information and given sufficiently high quality of elevation information, USPED may provide a more accurate sedimentation estimate than RUSLE using a generalized sediment delivery ratio $\left(\right.$ RUSLE $\left._{s d r}\right)$.

For each catchment, the RUSLE model (Renard et al. 1997) was

$T_{u p}=\operatorname{sdr} \Sigma n_{i} R_{i} K_{i} L S_{i} C_{i} P / \rho_{i}$,

where $T_{u p}$ was annual soil loss $\left(\mathrm{m}^{3} \cdot \mathrm{yr}^{-1}\right)$ from the catchment (summation over $\mathrm{n}$ catchment unit areas) per unit time. $R$ was rainfall erosivity $\left(\mathrm{MJ} \cdot \mathrm{mm} \cdot \mathrm{ha}^{-1} \cdot \mathrm{hr}^{-1} \cdot \mathrm{yr}^{-1}\right)$, and $K$ was the soil erodibility factor $\left(\mathrm{t} \cdot \mathrm{ha} \cdot \mathrm{hr} \cdot \mathrm{ha}^{-1} \cdot \mathrm{MJ}^{-1} \cdot \mathrm{mm}^{-1}\right.$; Foster et al. 1981). $L S$ was the dimensionless topographic factor that accounted for slope length and steepness, given by (upland unit area length/22.13 $)^{0.6}$ (sin slope $)^{1.3}$ with the exponents selected for rill erosion (Moore and Wilson 1992). $C$ was the cover management factor, dimensionless, determined from land cover. $\mathrm{P}$ was the conservation practice factor, dimensionless, and customarily set to 1 for large areas unless comparing specific field practices. We calculated sediment delivery ratio, $s d r$ (range 0 , no sediment reached the slope bottom, to -1 , all sediment reached the slope bottom), using the guideline provided by the USDA Soil Conservation Service (1983: Fig. 6-2) based on catchment size. The bulk density, $\rho\left(\mathrm{g} \cdot \mathrm{cm}^{-3}\right)$, was 
used to convert from metric tons to cubic meters of sediment. See Burris and Skagen (2012) for additional details of RUSLE methodology.

The USPED model (Online Resource 1, Fig. S1; Mitasova et al. 1996) was

$T_{i}=R_{i} K_{i} C_{i} P\left(A_{i} / 22.13\right)^{1.6}\left(\sin B_{i} / 0.0896\right)^{1.3} / \rho_{i}$,

where $T$ was soil transport capacity; $R, K, C, P$, and $\rho$ were as described for RUSLE. The topographic factor, $A^{1.6} \cdot\left(\sin B^{1.3}\right)$, was computed from elevation data, where $A$ was upslope contributing area calculated using GIS raster methods as within cell flow accumulation - cell size ( $30 \mathrm{~m}), B$ was slope angle, and the exponents were selected for rill erosion (Moore and Wilson 1992). The constants, 22.13 and 0.896, made the topographic factor dimensionless. To account for within slope changes in transport capacity (i.e., some portions of the catchment may be deposition rather than erosion locations), $T_{e d}$, the effective erosion/deposition from the slope, was computed as

Ted $=\sum_{i}^{n} d\left(T_{i} \cos a_{i}\right) / d x+d\left(T_{i} \sin a_{i}\right) / d y$

where the summation was over $n$ catchment unit areas, and $\alpha$ was the slope aspect (degrees, in the direction of steepest slope), and $x$ and $y$ were the length and width of each grid cell (30 m). (Mitasova et al. 1996, 2003; Mitas and Mitasova 1998; Mitasova and Mitas 1999; Warren et al. 2005).

For both models, we assumed that the volume of sediment displaced from the catchment was equal to that deposited in the wetland. For simplicity, we assumed wetlands were flat bottomed and filled evenly, thus sediment depth, SDepth $=T_{\text {up }} / A_{\text {wetland }}$ for RUSLE and SDepth $=T_{\text {ed }} / A_{\text {wetland }}$ for USPED, where $A_{\text {wetland }}$ was the area of the wetland, $\mathrm{m}^{2}$. The volume of sediment was compared to the basin volume to determine the loss of wetlands due to complete filling.

\section{Data Analyses}

To determine future change in precipitation across the study area, we calculated the difference between future average annual precipitation and 1981-2010 average annual precipitation by climate model (CSIRO, CGCM, or MIROC), scenario (A1B, A2, or B2), and future period (2011-2040, 2041-2070, or 2071-2100) at 126 random locations. Locations were at least $30 \mathrm{~km}$ apart to minimize spatial correlation. We used analysis of covariance to test for significant differences in the dependent variable annual sediment accumulation rate based on the covariates time period and land use using SAS 9.3 (SAS Institute 2002-2010).

We used the average annual deposition rate from 1981 to 2010 to estimate historic sediment accumulation at each wetland basin. Using projected R-factors of the nine future climate model/scenario combinations, we estimated sediment accumulation for each future period averaging annual accumulation rates over the 30 -year period. Wetland fill times were the number of years needed to fill the remaining wetland depth (based on volume loss). We assumed surface elevations corresponded to the vintage of the underlying Digital Elevation Model (DEM; USGS National Elevation Dataset Data Source Index, <http://ned.usgs.gov/). Most models were from 1970, so generally our estimated wetland depth loss due to sediment accumulation started in 1970 . We counted wetlands filled by 2010 , during each future period, and those that did not fill by 2100 . We also determined the number of wetlands that lost $50 \%$ of their volume by 2100 and those with average annual sediment rates greater than 0 . $5 \mathrm{~cm} \mathrm{yr}^{-1}$. We used the simplifying assumption that land use did not change from ca 1970 through 2100.

We compared our results against sediment accumulation rates empirically determined by two field studies in the region or nearby, Gleason (2001) and Preston et al. (2013). We selected wetlands comparable in basin size, catchment size, and geography in grassland and cropland contexts and using reported sample sizes, we created sampling distributions of mean (95\% confidence interval, CI) annual sediment accumulation rates based on 1000 random samples (e.g., for comparison with wetlands in cropland reported by Gleason [2001], we drew 1000 samples of 12 wetlands). We compared our results to the ${ }^{210} \mathrm{~Pb}$ results reported by Gleason (2001).

Because RUSLE and USPED are both general models based on widespread applicability across the U.S. (Renard et al. 1997), we investigated the relative importance of model variables in influencing rates of sediment accumulation in wetlands in the PPR. For this evaluation, we randomly selected ten $1 \%$ and one $10 \%$ sample of wetlands stratified by regime. These smaller samples improved computational tractability and improved the likelihood of sample independence. We evaluated the relative importance of six variables, four variables in the RUSLE $s d r$ model plus catchment and basin size, with annual sediment rate as the dependent variable, by contrasting $t$-values from an analysis of variance (Bring 1994). Specifically, we expressed a ratio of the $t$-value of the variable of interest divided by the maximum $t$-value of all considered variables. We saw no significant difference between the 10 small samples and the single large sample, so only the large $(10 \%)$ sample is reported here. To further examine the relative contribution of land use and precipitation to sediment accumulation determined by $\mathrm{RUSLE}_{s d r}$, we compared total sediment accumulation between land uses: grassland and cropland and between two 30-yr. time periods: 1981-2010 and 2041-2070 using analysis of variance (ANOVA). To do so, from the above-mentioned $10 \%$ sample, we selected a subset that included only wetlands that were not predicted to fill before 2070 and 
were situated in uplands of at least $75 \%$ cropland or $75 \%$ grassland.

\section{Results}

We delineated 1,568,217 catchments and estimated sediment infilling in their associated wetland basins across seven subecoregions within the study area; see Fig. 1 for delineation of the subecoregions. Distribution and characteristics of the wetland basins and the surrounding landscape varied by subecoregion (Fig. 2). Temporary and seasonal wetlands predominated in absolute number in all subecoregions and were most numerous along the Missouri Coteau and in the drift prairies of North and South Dakota (Table 1, Fig. 2). Grassland predominated in the coteau regions and cropland in the drift prairies.

During the climate reference period (1981-2010), annual precipitation across the study area averaged $586 \mathrm{~mm} \mathrm{yr}^{-1}$ (range 346-905 $\mathrm{mm} \mathrm{yr}^{-1}$ across space and time) and increased from west to east (Fig. 3). During the reference period, there were distinct cycles of wet and dry periods, indicating
Fig. 2 Variation in wetland basin and landscape characteristics by subecoregions within the U.S. Prairie Pothole Region (U.S. PPR) portrayed in Fig. 1

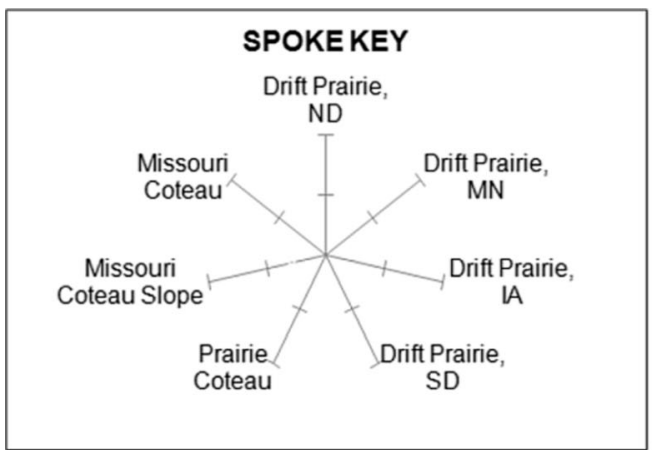

BASINS PER SUBECOREGION

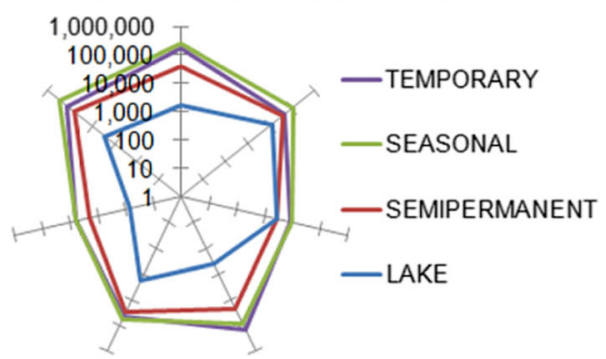

WETLAND REGIME MIX

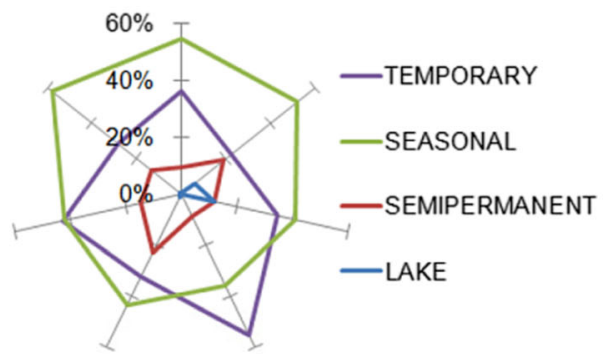

MEAN WATERSHED SLOPE

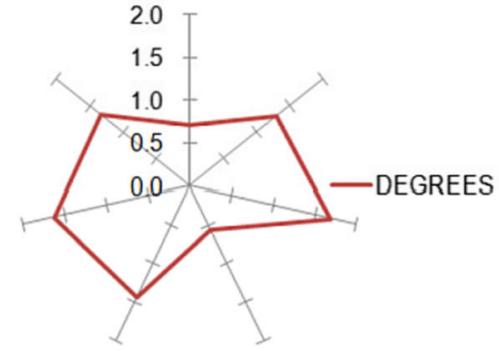

\section{SUBECOREGION AREA}

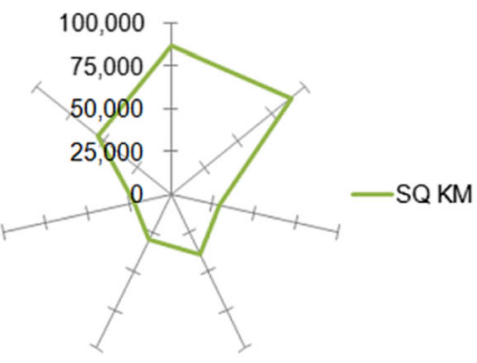

WETLAND PERCENTOF SUBECOREGION

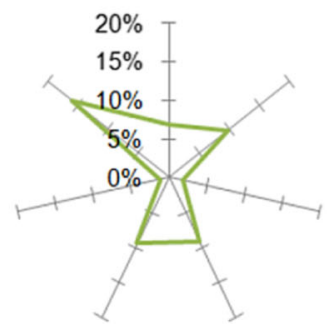

WATERSHED LANDUSE

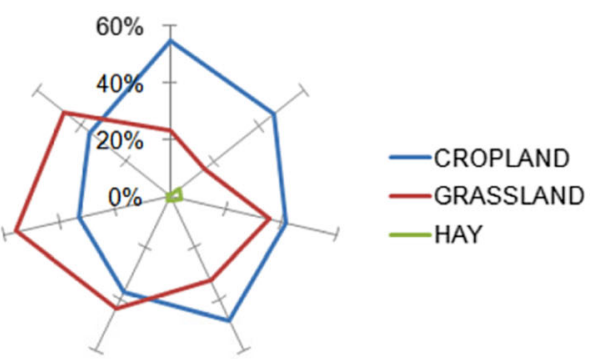

MEDIAN WATERSHED AREA

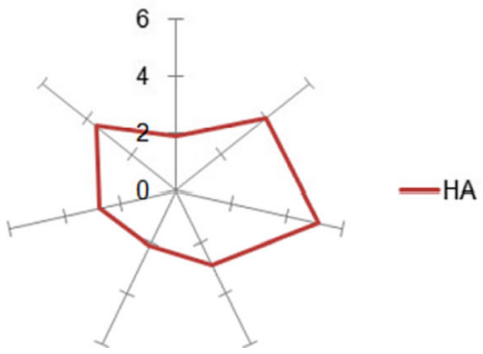


Fig. 3 Historic and predicted average annual precipitation $\left(\mathrm{mm} \mathrm{yr}^{-1}\right)$ within the study region portion of the U.S. Prairie Pothole Region (U.S. PPR). Upper left: Average annual precipitation during a 30-yr reference period, 1981-2010; upper right: Average difference in annual precipitation relative to the reference period during a deluge (wet) period, 1994-2001; center right: Precipitation difference during a drought (dry) period, 1987-1992, relative to the reference period. Bottom row: Average annual precipitation relative to the reference period during three future periods: 2011-2040, 2041-2070, and 2071-2100 using the downscaled climate model CGCM2.1MR, A2 emissions scenario. Lines denote subecoregions portrayed in Fig. 1
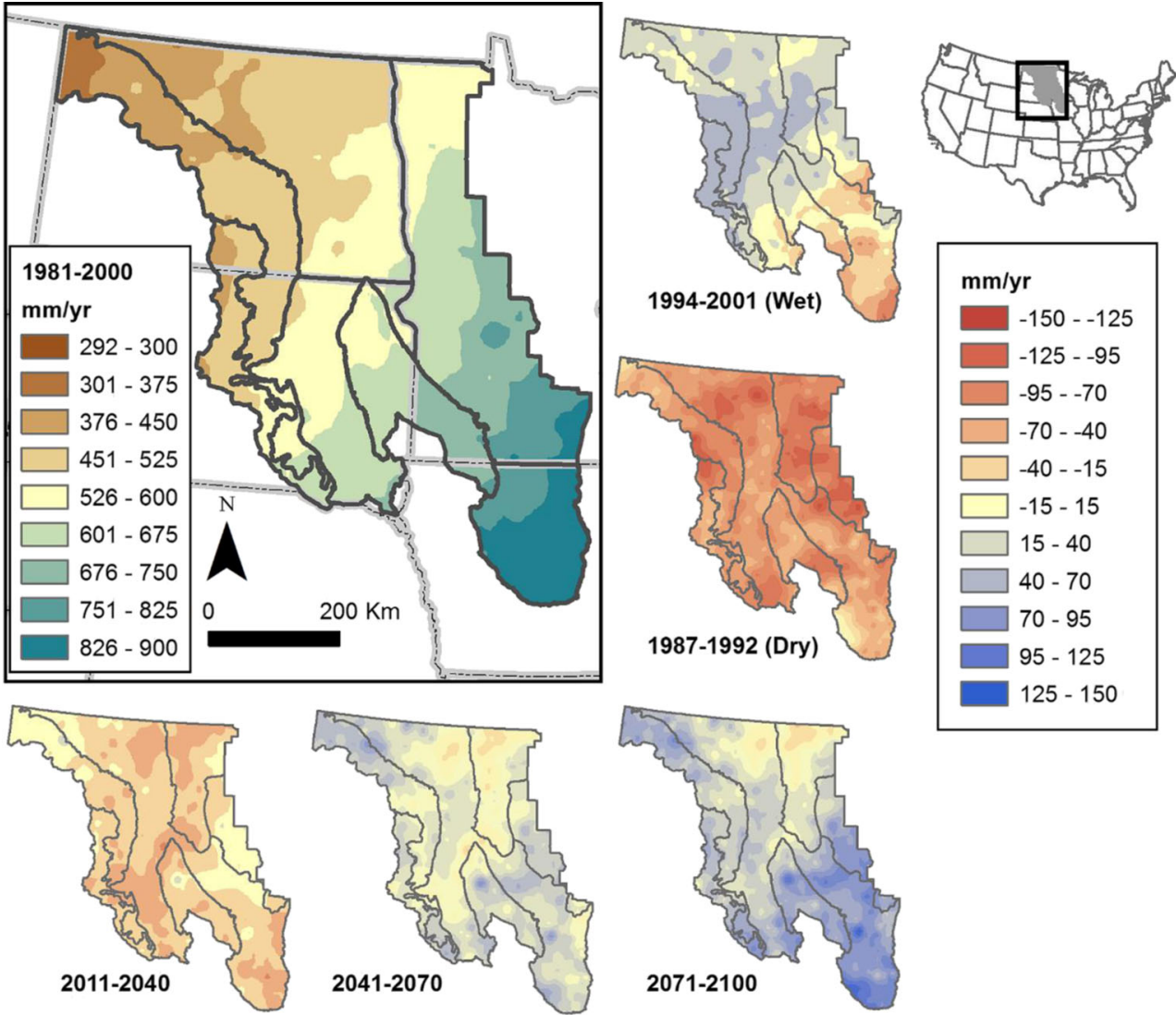

estimated that $43 \%$ of wetlands filled with sediments by 2100 , whereas RUSLE Sdr $_{r}$ and USPED, generally in agreement, estimated that $33 \%$ and $21 \%$ of all wetlands filled with sediments, respectively. The largest divergences between the latter two methods were in the drift prairies of Minnesota and Iowa where estimates varied by $20-29 \%$, depending on wetland regime (Table 1). Because RUSLE Sdr $_{r}$ and USPED provide more conservative and potentially more accurate values and were generally in agreement with one another, hereafter we report only projections of these two approaches.

Vulnerability to infilling did not vary markedly by wetland regime, although temporary wetlands and seasonal wetlands were slightly more likely to fill with sediments by 2100 (Fig. 4a; RUSLE $s d r 33,34 \%$, USPED 26, $19 \%$ ) than semipermanent wetlands ( RUSLE $_{s d r} 30 \%$, USPED $15 \%$ ). The largest absolute numbers of wetlands expected to infill with sediment by 2100 occurred along the Missouri Coteau $\left(\operatorname{RUSLE}_{s d r} 142\right.$, 982, USPED 90,144) and in the drift prairies of North Dakota (RUSLE $_{s d r}$ 142,704, USPED 91,223). By percentage, wetlands in the Drift Prairie of Iowa and Minnesota were particularly vulnerable to infilling (RUSLE S $_{s d r} 63 \%, 47 \%$; USPED $38 \%, 24 \%$, respectively).

We calculated two additional metrics that depict sediment accumulation rates: (1) the numbers (and percentages) of basins that will lose $50 \%$ of their volume by 2100 , and (2) the numbers (and percentages) of basins tive estimates than RUSLE. Across all categories, RUSLE 

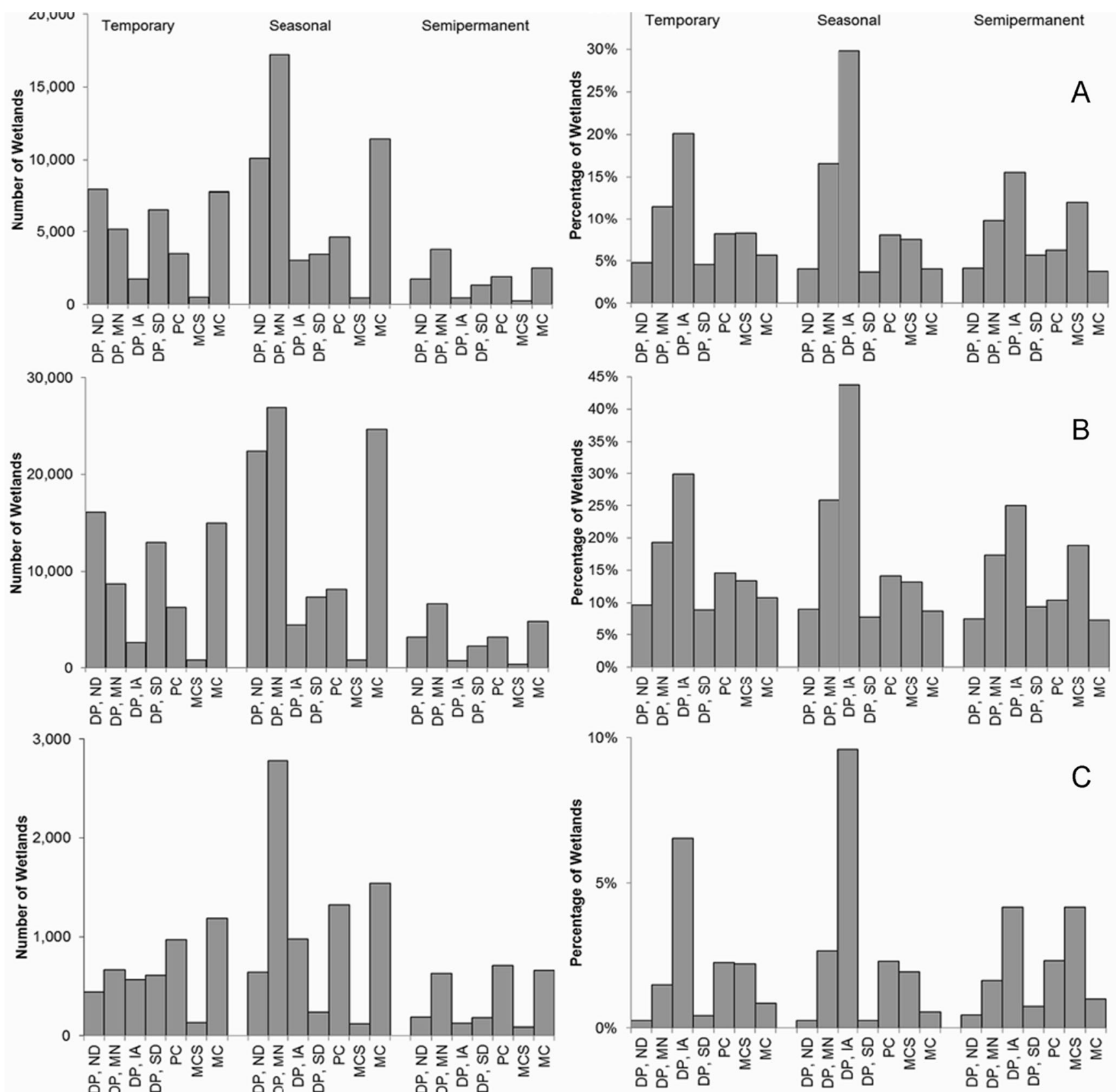

Fig. 4 Number (left) and percentage (right) of wetland basins within the U.S. Prairie Pothole Region (U.S. PPR) by subecoregion (defined in Fig. 1) and wetland type projected to a completely fill with sediments by

2100 , b lose $50 \%$ of their storage volume by 2100 , and $\mathbf{c}$ accumulate at least $0.5 \mathrm{~cm}$ of sediment per year

that will accumulate at least $0.5 \mathrm{~cm}$ of sediment annually through 2100 (Fig. 4b,c). Although estimates vary according to subecoregion, wetland regime, and method used, approximately $27-46 \%$ RUSLE $_{s d r} 46 \%$, USPED $27 \%$ ) of wetlands will lose half of their volume in the next century and 11-16\% (RUSLE R $_{s r} 16 \%$, USPED $11 \%$,) of basins will fill at a rate of $>0.5 \mathrm{~cm} \mathrm{yr}^{-1}$. As with complete infilling, the largest numbers of vulnerable wetlands were in the drift prairies of North Dakota and along the Missouri Coteau, and by

percentage, wetlands in the Drift Prairie of Iowa and Minnesota were particularly vulnerable (Fig. 4).

\section{Comparison with Empirical Studies}

Our predicted annual sediment accumulation rates were similar to those reported by the two empirical field studies in the region (Table 2). The $95 \%$ CIs for our comparative sample overlapped with the $95 \%$ CIs reported by Gleason (2001) for seasonal and semipermanent across the Prairie Pothole Region 
Table 2 Comparison of vertical sediment accumulation rates for wetlands situated in cropland and grassland for this study and others

\begin{tabular}{|c|c|c|c|c|c|}
\hline \multirow[t]{2}{*}{ Method } & \multirow[t]{2}{*}{ Source } & \multicolumn{2}{|l|}{ Grassland } & \multicolumn{2}{|l|}{ Cropland } \\
\hline & & $\mathrm{N}(n)^{\mathrm{a}}$ & Accumulation rate $\left(\mathrm{cm} \mathrm{yr}^{-1}\right)(95 \% \mathrm{CI})$ & $\mathrm{N}(n)^{\mathrm{a}}$ & $\begin{array}{l}\text { Accumulation rate } \\
\left(\mathrm{cm} \mathrm{yr}^{-1}\right)(95 \% \mathrm{CI})\end{array}$ \\
\hline \multicolumn{6}{|c|}{ Semipermanent and seasonal wetlands across the PPR } \\
\hline \multirow{2}{*}{$\begin{array}{l}\text { RUSLE }_{s d r} \\
{ }^{210} \mathrm{~Pb}\end{array}$} & This study & $1621(7)$ & $0.03(0.01-0.07)$ & $1730(12)$ & $0.16(0.07-0.30)$ \\
\hline & Gleason 2001 & (7) & $0.08(0.02-0.14)$ & $(12)$ & $0.27(0.23-0.31)$ \\
\hline \multicolumn{6}{|c|}{ Seasonal wetlands in the Montana Missouri Coteau ${ }^{\mathrm{b}}$} \\
\hline \multirow{2}{*}{$\begin{array}{l}\text { RUSLE }_{s d r} \\
{ }^{210} \mathrm{~Pb}\end{array}$} & This study & $596(4)$ & $0.03(0.01-0.09)$ & $354(4)$ & $0.23(0.06-0.55)$ \\
\hline & Preston et al. 2013 & (4) & $0.06(0.05-0.10)$ & (4) & $0.21(0.15-0.30)$ \\
\hline
\end{tabular}

${ }^{a} \mathrm{~N}$ reflects the population of wetlands and $n$ the sample size drawn from the population. Confidence intervals were based on random draws using the sample size of the comparison study

${ }^{\mathrm{b}}$ As our study did not extend into Montana, our comparison is with nearby North Dakota Missouri Coteau wetlands

(Montana, North Dakota, South Dakota, Minnesota, and Iowa) embedded in both grasslands and croplands; our point estimates were nonsignificantly lower. An empirical study conducted in the neighboring state of Nebraska reported similar annual sediment accumulation rates ranging from $0.18 \mathrm{~cm} \mathrm{yr}^{-1}$ to $0.29 \mathrm{~cm} \mathrm{yr}^{-1}$ (Tang et al. 2015). Wetlands embedded in agricultural fields had greater (non-overlapping $95 \%$ CIs) annual sediment accumulation rates than wetlands surrounded by predominantly grassland in both Gleason's and our studies (Table 2). The $95 \%$ CIs of annual sediment accumulation rates for our comparative sample also overlapped with the intervals reported by Preston et al. (2013) for seasonal wetlands in the Montana Missouri Coteau embedded in both grasslands and croplands. Preston et al. (2013) also reported greater (non-overlapping $95 \%$ CIs) annual sediment accumulation rates for wetlands embedded in agricultural fields than wetlands in grassland contexts.

\section{Relative Importance of Covariates}

Across the entire region, variation in rates of sediment accumulation were most strongly explained by three of six covariates $(F=129,344, d f=6,142,252, p<0.0001)$, the size of the catchment $(t=479.06$; relative importance $[t$-value ratio $]=1)$, land use $(C$; relative importance $=0.959)$; and slope (relative importance $=0.930$ ). Sediment accumulation was greater in wetlands in larger catchments and wetlands surrounded by steeper slopes; accumulation increased as coverage of tilled landscape within the catchment increased. Wetland basin size explained an intermediate amount of the variation in accumulation rates (relative importance $=0.770$ ), with greater rates for smaller wetlands. Annual precipitation (as expressed by $R$; relative importance 0.196$)$ and soil erodibility $(K$, based on soil type; relative importance 0.132 ) were the least influential of the six factors in explaining variation in sediment accumulation rates. All covariates were statistically significant $(p<0.0001)$, and the amount of variance explained was high $\left(R^{2}=0.845\right)$.

Depth of sediment accumulation in wetlands $(n=48,528)$ that did not fill prior to 2070 were estimated for periods of contemporary and projected climate to further evaluate the relative importance of land use and future changes in precipitation. This subset of wetlands experienced lower vulnerability than the population as a whole because one criterion for subset selection was lack of complete infilling by 2070 . In this subset of less vulnerable wetlands, sediment accumulation in wetlands surrounded by croplands was $2-3$ times more than in wetlands surrounded by in grasslands, and sediment accumulation was greater in 2041-2070 than 1981-2010 in cropland settings only (Table 3 ). Based on average precipitation, land use had a stronger influence on sediment accumulation than precipitation for all wetland regimes (Table 3 ). The differences attributable to land use were 10-fold greater than differences associated with changing precipitation.

\section{Discussion}

Our study suggests that sedimentation warrants strong concern as a conservation issue because nearly one-third of wetlands in the U.S. Prairie Pothole Region may fill with sediments within the next century. The extent to which sedimentation may alter viability and function of individual wetlands across this region has not been explored previously, perhaps because sediment accumulation is a more subtle change agent than land and hydrologic alteration. Moreover, our estimates of sediment accumulation rates may be conservative if more annual precipitation manifests in the future than was predicted by the models used in this study. Our estimates of sediment accumulation rates were based on climate models that collectively predicted a range of future precipitation including both drier and wetter conditions. Climate predictions summarized by Ballard et al. (2014: Fig. 11), 
Table 3 Average sediment accumulation depth $(95 \% \mathrm{CI}$ $\mathrm{cm}$ ) by land use and wetland regime for a subset of wetlands predicted to fill after 2070 during periods of contemporary climate (1981-2010) and projected climate (2041-2070) using RUSLE $_{s d r}$

\begin{tabular}{|c|c|c|c|c|}
\hline \multirow[b]{2}{*}{ Regime } & \multirow[t]{2}{*}{ Time period } & \multicolumn{2}{|l|}{ Surrounding upland } & \multirow{2}{*}{$\begin{array}{l}\text { Difference between } \\
\text { land uses }\end{array}$} \\
\hline & & Grassland & Cropland & \\
\hline \multirow[t]{3}{*}{ Temporary } & & $n=5950$ & $n=13,073$ & \\
\hline & 1981-2010 & $1.18(1.12,1.23)$ & $2.26(2.23,2.30)$ & $1.09(1.00,1.18) *$ \\
\hline & $2041-2070$ & $1.22(1.16,1.27)$ & $2.37(2.34,2.41)$ & $1.16(1.07,1.25) *$ \\
\hline \multicolumn{2}{|c|}{ Difference between time periods } & $0.40(-0.07,0.14)^{\mathrm{ns}}$ & $0.11(0.04,0.18)^{*}$ & \\
\hline \multirow[t]{3}{*}{ Seasonal } & & $n=14,021$ & $n=10,739$ & \\
\hline & 1981-2010 & $1.34(1.30,1.39)$ & $3.49(3.44,3.54)$ & $2.14(2.05,2.23) *$ \\
\hline & $2041-2070$ & $1.43(1.38,1.47)$ & $3.71(3.66,3.76)$ & $2.29(2.20,2.38) *$ \\
\hline \multicolumn{2}{|c|}{ Difference between time periods } & $0.08(0.00,0.16)^{\mathrm{ns}}$ & $0.22(0.13,0.32)^{*}$ & \\
\hline \multicolumn{2}{|c|}{ Semipermanent } & $n=3,285$ & $n=1,460$ & \\
\hline & $1981-2010$ & $1.80(1.67,1.93)$ & $6.26(6.07,6.45)$ & $4.46(4.16,4.76) *$ \\
\hline & $2041-2070$ & $1.89(1.77,2.02)$ & $6.65(6.45,6.84)$ & $4.75(4.45,5.05) *$ \\
\hline \multicolumn{2}{|c|}{ Difference between time periods } & $0.09(-0.14,0.33)^{\mathrm{ns}}$ & $0.39(0.03,0.74)^{*}$ & \\
\hline
\end{tabular}

Wetland functionality, habitat suitability, and food resources for vertebrate species can be significantly impacted not only by partial or complete infilling by sediments, but also by an annual sediment accumulation rate sufficient to suppress the emergence of aquatic invertebrates. A relatively small proportion but a sizeable number of wetlands experienced annual accumulation rates of $>0.5 \mathrm{~cm} \mathrm{yr}^{-1}$, the rate at which the emergence of plants and aquatic invertebrates from wetland seed and egg banks is $90-100 \%$ suppressed (Jurik et al. 1994; Gleason et al. 2003). These wetlands may continue to provide the visual cues associated with suitable habitat and will likely attract birds, mammals, and amphibians that forage on emerging insects, but in actuality these wetlands may serve as ecological traps (sensu Schlaepfer et al. 2002).

The ability of landscape and wetland attributes to explain variability in sediment accumulation rates across the study area was greater than that of projected increasing precipitation with climate change. Across the study area, the wetlands most at risk of infilling were embedded in large catchments and a matrix primarily of cropland and often surrounded by steep slopes. Increased soil erosion in cropland relative to grassland was acknowledged by the developers of RUSLE based on empirical evidence and reflected in the $C$-factor (Renard et al. 1997). Our finding of greater sediment accumulation rates for wetlands within cropland matrices, possibly due to altered surface water flow, was consistent with earlier empirical studies (Luo et al. 1997, Gleason 2001; Preston et al. 2013) and not unexpected. Here we report that other landscape attributes (catchment size, steepness of the topography, and basin size) also play major roles in explaining variation in accumulation rates across the U.S. Prairie Pothole region.

This study provides a broadscale picture of projected sedimentation rates in the USPPR but does not account for all potential factors. We were unable to address the predicted 
increases in storm intensity (Karl et al. 1995) nor the potential changes in seasonality of storms because of the annual timestep used in calculating erosivity (from precipitation) in RUSLE and USPED. We were also unable to address the influence of hydrologic manipulations such as drainage ditches, tile drains, and resulting consolidation drainage on runoff and sedimentation patterns (Anteau 2012; McCauley et al. 2015) as well as wind erosion that may deliver sediments from unvegetated landscapes into wetlands. For our analyses, we assumed static land use patterns and did not attempt to project recent and future changes in land use or additional conversion of grassland to cropland (sensu Johnston 2013; Wright and Wimberly 2013). Estimates of risk of conversion of existing grasslands to cultivated croplands range from $0.4 \%$ to $1.33 \%$ annualized loss (Stephens et al. 2008; Rashford et al. 2010). The sediment accumulation rates we present are likely conservative because the land cover data we used did not capture the rapid conversion of grassland to cropland that has occurred since 2000 (Rashford et al. 2010).

Sedimentation rates are determined not only by topographic features (catchment size, slope, basin size) and rainfall, but especially by land use practices. Our finding of greater sediment accumulation in wetlands embedded in tilled cropland rather than grassland matrices is in agreement with earlier studies here and in more southern regions of the Great Plains (Gleason 2001; Burris and Skagen 2012; Preston et al. 2013). Several authors have recommended that conservation efforts be developed to strategically target grasslands and wetlands with high ecological value that are at high risk of conversion (Stephens et al. 2008; Rashford et al. 2010; Anteau 2012). Wetland-dependent biota may benefit if such efforts also incorporate the relative risk of wetland sediment infilling and thus emphasize conservation actions in areas of large watersheds and high topographic relief, especially in landscapes of predominantly cropland.

\footnotetext{
Acknowledgments Technical support was provided by Colorado State University, Department of Anthropology Geospatial Laboratory. This research was funded by the U.S. Geological Survey Science Support Program, the U.S. Geological Survey National Climate Change and Wildlife Science Center, the Plains and Prairie Potholes Landscape Conservation Cooperative, and the Department of Interior North Central Climate Science Center. Glenn Guntenspergen reviewed an earlier draft of this manuscript. Any use of trade, firm, or product names is for descriptive purposes only and does not imply endorsement by the U. $\mathrm{S}$. Government. The findings and conclusions in this article are those of the author(s) and do not necessarily represent the views of the U.S. Fish and Wildlife Service.
}

Open Access This article is distributed under the terms of the Creative Commons Attribution 4.0 International License (http:// creativecommons.org/licenses/by/4.0/), which permits unrestricted use, distribution, and reproduction in any medium, provided you give appropriate credit to the original author(s) and the source, provide a link to the Creative Commons license, and indicate if changes were made.

\section{References}

Anteau MJ (2012) Do interactions of land use and climate affect productivity of waterbirds and prairie-pothole wetlands? Wetlands 32:1-9

Balas CJ, Euliss NH Jr, Mushet DM (2012) Influence of conservation programs on amphibians using seasonal wetlands in the Prairie Pothole Region. Wetlands 32:333-345

Ballard T, Seager R, Smerdon JE, Cook BI, Ray AJ, Rajagopalan B, Kushnir Y, Nakamura J, Henderson N (2014) Hydroclimate variability and change in the Prairie Pothole Region, the "duck factory" of North America. Earth Interact 18:1-28. doi:10.1175/EI-D-14-0004.1

Batt BDJ, Anderson MG, Anderson CD, Anderson DC, Caswell DF (1989) The use of prairie potholes by North American ducks. In: van der Valk AG (ed) Northern Prairie wetlands. Iowa State University Press, Ames, Iowa, USA, pp. 204-229

Bring J (1994) How to standardize regression coefficients. Am Stat 48: 209-213

Burris L, Skagen SK (2012) Modeling sediment accumulation in North American playa wetlands in response to climate change, 1940-2100. Clim Chang 117:69-83

Christensen JH, Hewitson B, Busuioc A, et al. (2007) Regional climate projections. In: Solomon S, Qin D, Manning M, et al. (eds) Climate change 2007: the physical science basis. Contribution of Working Group I to the fourth assessment report of the Intergovernmental Panel on Climate Change. Cambridge University Press, New York, pp. 849-940

Coulson DP, Joyce LA, Price DT, McKenney DW, Siltanen RM, Papadopo P, Lawrence K (2010) Climate scenarios for the conterminous United States at the 5 arc minute grid spatial scale using SRES scenarios A1B and A2 and PRISM climatology. US Department Of Agriculture Forest Service. Rocky Mountain Research Station, Fort Collins, CO, USA

Cowardin LM (1982) Some conceptual and semantic problems in wetland classification and inventory. Wildl Soc Bull 10:57-60

Cowardin LM, Carter V, Golet FC, LaRoe ET (1995) Classification of wetlands and deepwater habitats of United States. FWS/OBS-79/31. US Department of the Interior, Fish and Wildlife Service, Washington, DC

Dahl TE (1990) Wetland losses in the United States 1780s to 1980s. U.S. Department of the Interior, Fish and Wildlife Service, Washington DC

Dahl TE (2011) Status and trends of wetlands in the conterminous United States 2004 to 2009. US Department Of The Interior, Fish and Wildlife Service, Washington, DC

Daniel DW, Smith LM, Haukos DA, Johnson LA, McMurry ST (2014) Land use and Conservation Reserve program effects on the persistence of playa wetlands in the High Plains. Environ Sci Technol 48(8):4282-4288

Donald DB, Syrgiannis J, Hunter F, Weiss G (1999) Agricultural pesticides threaten the ecological integrity of northern prairie wetlands. Sci Total Environ 231:173-181

Environmental Systems Research Institute (ESRI) (1999-2008) ArcGIS version 9.3. Redlands, CA, USA

Foster GR, McCool DK, Renard KG, Moldenhauer WC (1981) Conversion of the universal soil loss equation to SI metric units. J Soil Water Conserv 36:355-359

Gesch DB (2007) The National Elevation Dataset. In: Maune D (ed) Digital elevation model technologies and applications: the DEM users' manual, 2nd edn. American Society for Photogrammetry and Remote Sensing, Bethesda, Maryland, USA, pp. 99-118

Gesch D, Oimoen M, Greenlee S, Nelson C, Steuck M, Tyler D (2002) The National Elevation Dataset. Photogramm Eng Remote Sens 68: $5-11$ 
Gleason RA (2001) Invertebrate egg and plant seed banks in natural, restored, and drained wetlands in the Prairie Pothole Region (USA) and potential effects of sedimentation on recolonization of hydrophytes and aquatic invertebrates. South Dakota State University, Brookings, South Dakota, USA, Dissertation

Gleason RA, Euliss NH Jr (1998) Sedimentation of prairie wetlands. Great Plains Res 8:97-112

Gleason RA, Euliss NH Jr, Hubbard DE, Duffy WG (2003) Effects of sediment load on emergence of aquatic invertebrates and plants from wetland soil egg and seed banks. Wetlands 23:26-34

Gleason RA, Tangen BA, Laubhan MK, Kermes KE, Euliss NH Jr (2007) Estimating water storage capacity of existing and potentially restorable wetland depressions in a subbasin of the Red River of the North. Reston. US Geological Survey Open File Report 2007-1159

Johnson RR, Higgins KF (1997) Wetland resources of Eastern South Dakota. South Dakota State University, Brookings, South Dakota, USA

Johnson WC, Millett BV, Gilmanov T, Voldseth RA, Guntenspergen GR, Naugle DE (2005) Vulnerability of northern prairie wetlands to climate change. Bioscience 55:863-872

Johnson RR, Oslund FT, Hertel DR (2008) The past, present, and future of prairie potholes in the United States. J Soil Water Conserv 63: $84 \mathrm{~A}-87 \mathrm{~A}$

Johnston CA (2013) Wetland losses due to row crop expansion in the Dakota Prairie Pothole Region. Wetlands 33:175-182

Jurik TW, Wang SC, van der Valk AG (1994) Effects of sediment load on seedling emergence from wetland seedbanks. Wetlands 14:159-165

Karl TR, Knight RW, Plummer N (1995) Trends in high frequency climate variability in the 20th century. Nature 377:217-220

Kehew AE, Teller JT (1994) History of late glacial runoff along the southwestern margin of the laurentide ice sheet. Quat Sci Rev 13: 859-877

Luo H-R, Smith LM, Allen BL, Haukos DA (1997) Effects of sedimentation on playa wetland volume. Ecol Appl 7:247-252

McCauley LA, Anteau MJ, Post van der Burg M, Wiltermuth MT (2015) Land use and wetland drainage affect water levels and dynamics of remaining wetlands. Ecosphere 6(6):92. http://dx.doi.org/10.1890/ ES14-00494.1

Millett B, Johnson WC, Guntenspergen G (2009) Climate trends of the North American prairie pothole region 1906-2000. Clim Chang 93: 243-267

Mitas L, Mitasova H (1998) Distributed soil erosion simulation for effective erosion prevention. Water Resour Res 34(3):505-516

Mitasova HA, Mitas L (1999) Erosion/deposition modeling with USPED using GIS. University of Illinois, Urbana-Champaign, Illinois, USA. Available http://www4.ncsu.edu/ helena/gmslab/ denix/usped.html

Mitasova HA, Hofierka J, Zlocha M, Iverson LR (1996) Modeling topographic potential for erosion and deposition using GIS. Int J Geogr Inf Sci 10:629-641

Mitasova HA, Brown WM, Hohmann M, Warren S (2003) Using soil erosion modeling for improved conservation planning: a GIS-based tutorial. University of Illinois, Urbana-Champaign, Illinois, USA. Available http://www4.ncsu.edu/ helena/gmslab/reports/ CerlErosionTutorial/denix/default.html

Moore ID, Wilson JP (1992) Length-slope factors for the revised Universal soil loss equation: simplified method of estimation. J Soil Water Conserv 47:423-428

Murkin HR, Murkin EJ, Ball JP (1997) Avian habitat selection and prairie wetland dynamics: a 10-year experiment. Ecol Appl 7:1144-1159

Natural Resources Conservation Service (2000) National Resources Inventory, 1997. U.S. Department of Commerce, Washington, DC, USA

Niemuth ND, Estey ME, Reynolds RE, Loesch CR, Meeks WA (2006) Use of wetlands by spring migrant shorebirds in agricultural landscapes of the drift prairie of North Dakota. Wetlands 26:30-39
Oslund FT, Johnson RR, Hertel DR (2010) Assessing wetland changes in the Prairie Pothole Region of Minnesota from 1980 to 2007. J Fish Wildl Manag 1:131-135

Pachauri RK, Reisinger A (eds) (2007) Climate change: synthesis report. Contribution of working groups I, II, and III to the fourth assessment report of the Intergovernmental Panel on Climate Change, Intergovernmental Panel on Climate Change, Geneva, Switzerland

Preston TM, Sojda RS, Gleason RA (2013) Sediment accretion rates and sediment composition in Prairie Pothole wetlands under varying land use practices, Montana, United States. J Soil Water Conserv 68:199-211

Rashford BS, Walker JA, Bastian CT (2010) Economics of grassland conversion to cropland in the Prairie Pothole Region. Conserv Biol 25:276-284

Renard KG, Freimund JR (1994) Using monthly precipitation data to estimate the R-factor in the revised USLE. J Hydrol 157:287-306

Renard KG, Foster GA, Weesies GR, McCool DK, Yoder DC (1997) Predicting soil erosion by water: a guide to conservation with the revised soil loss equation (RUSLE). Agriculture Handbook No. 703. U.S. Department of Agriculture, Agricultural Research Service, Washington DC, $404 \mathrm{p}$

Reynolds RE, Shaffer TL, Loesch CR, Cox RR Jr (2006) The farm bill and duck production in the Prairie Pothole Region: increasing the benefits. Wildl Soc Bull 34:963-974

SAS Institute (2002-2010) SAS version 9.3. Cary, North Carolina, USA.

Schlaepfer MA, Runge MC, Sherman PW (2002) Ecological and evolutionary traps. Trends Ecol Evol 17:474-480

Skagen SK, Granfors DA, Melcher CP (2008) On determining the significance of ephemeral continental wetlands to North American migratory shorebirds. Auk 125:20-29

Smith LM, Haukos DA, McMurry ST, LaGrange T, Willis D (2011) Ecosystem services provided by playas in the High Plains: potential influences of USDA conservation programs. Ecol Appl 21:S82-S92

Snodgrass JW, Komoroski MJ, Bryan AL Jr, Burger J (2000) Relationships among isolated wetland size, hydroperiod, and amphibian species richness: implications for wetland regulations. Conserv Biol 14:414-419

Soil Survey Staff (2009) Soil survey geographic (SSURGO) database for Iowa, Minnesota, North Dakota, and South Dakota. USDA Natural Resources Conservation Service, available http://soildatamart.nrcs. usda.gov

Stephens SE, Walker JA, Blunck DR, Jayaraman A, Naugle DE, Ringelman JK, Smith AJ (2008) Predicting risk of habitat conversion in native temperate grasslands. Conserv Biol 22:1320-1330

Sylvester KM, Brown DG, Deane GD, Kornak RN (2013) Land transitions in the American plains: multilevel modeling of drivers of grassland conversion (1956-2006). Agric Ecosyst Environ 168:7-15

Tang Z, Gu Y, Drahota J, LaGrange T, Bishop A, Kuzila MS (2015) Using fly ash as a marker to quantify culturally-accelerated sediment accumulation in playa wetlands. J Am Water Resour Assoc. doi:10. $1111 / 1752-1688.12347$

Tangen BA, Gleason, RA (2008) Reduction of sedimentation and nutrient loading. In: Gleason RA, Laubhan MK, Euliss NH Jr (eds) Ecosystem services derived from wetland conservation practices in the United States Prairie Pothole Region with an emphasis on the US Department of Agriculture Conservation Reserve and Wetlands Reserve Programs. US Geological Survey Reston, Virginia, USA, Professional Paper 1745:38-44

Thogmartin WE, Gallant AL, Knutson MG, Fox TJ, Suarez MJ (2004) A cautionary tale regarding use of the National Land Cover Dataset 1992. Wildl Soc Bull 32:970-978

Tiner RW Jr (1984) Wetlands of the United States: current status and recent trends. US Government Printing Office, Washington, DC

Tiner RW Jr (2003) Geographically isolated wetlands of the United States. Wetlands 23:494-516 
Tsai J-S, Venne LS, Smith LM, McMurry ST, Haukos DA (2012) Influence of local and landscape characteristics on avian richness and density in wet playas of the Southern Great Plains, USA. Wetlands 32:605-618

US Department of the Interior (2009) Fish and Wildlife Service, National Wetlands Inventory Available http://www.fws.gov/ wetlands/DATA/

USDA Soil Conservation Service (1983) National Engineering Handbook: section 3, sedimentation, chapter 6, sediment sources, yields, and delivery ratios. Washington, DC

van der Kamp G, Hayashi M (1998) The groundwater recharge function of small wetlands in the semi-arid northern prairies. Great Plains Res $8: 39-56$
Venne LS, Tsai J-S, Cox SB, Smith LM, McMurry ST (2012) Amphibian community richness in cropland and grassland playas in the Southern High Plains, USA. Wetlands 32:619-629

Warren SD, Mitasova H, Hohmann MG, Landsberger S, Iskander FY, Ruzycki TS, Senseman GM (2005) Validation of a 3-D enhancement of the Universal soil loss equation for prediction of soil erosion and sediment deposition. Catena 64(2-3):281-296

Winter TC, Rosenberry DO (1995) The interaction of ground water with prairie pothole wetlands in the cottonwood Lake area, east Central North Dakota, 1979-1990. Wetlands 15:193-211

Wright CK, Wimberly MC (2013) Recent land use change in the Western Corn Belt threatens grasslands and wetlands. Proc Natl Acad Sci 110:4134-4141 